\title{
Using marine models to road-test climate-smart management responses and strategies and prepare decision makers
}

\author{
$\underline{\text { É.E. Plagányia }}^{\mathrm{a}}$ and A.J. Hobday ${ }^{\mathrm{b}}$ \\ ${ }^{a}$ CSIRO Oceans and Atmosphere Flagship, Queensland BioSciences Precinct (QBP), St Lucia, Brisbane, \\ Queensland, 4072 \\ ${ }^{b}$ CSIRO Oceans and Atmosphere Flagship, GPO Box 1538, Hobart, Tasmania 7004
}

Email: Eva.Plaganyi-lloyd@,csiro.au

\begin{abstract}
Preparation for climate change and responding appropriately to extreme events and abrupt changes in the state and organisation of ecosystems, and their dependent societies, is aided by pre-testing of strategies and adaptation options. Simulation modeling can facilitate understanding of the underlying drivers and system responses as well as appropriate monitoring, and can assist in planning for both gradual and abrupt future change. Here we first present a framework to map the flows from changes in physical drivers impacting biological systems through to their impact on socio-economic systems. We then suggest actions that could be taken as a perturbation propagates through the system, and examine several modeling tools that are being used to road-test climate-smart management responses, strategies or to inform design of adaptation options. Through case study examples we focus on (1) the use of multispecies models to advance our ability to anticipate or deal with major ecosystem shifts, (2) illustrate how the outputs of models, such as seasonal forecast models, can be used to adaptively respond to changes, and (3) the use of management strategy evaluation (MSE) to account for uncertainties and test the performance of alternative marine monitoring and management strategies to detect and respond to ecological changes caused by climate change.
\end{abstract}

Our examples illustrate that models need not be overly complex to be useful. For example, we show that an intermediate complexity modelling approach assists in understanding the underlying mechanisms (e.g. nonlinear changes in population parameters below critical prey thresholds may contribute to the responses of predators to changes in their prey) as well as in identifying early warning signals (e.g. increasing variance in population monitoring data may signal a forthcoming abrupt decline). Similarly, forecasting models can provide information on seasonal time scales, allowing proactive decision making by a range of users. Seasonal forecasting is already being used in Australia in a range of marine farming and fishing operations to reduce uncertainty and manage business risks. Species-specific habitat forecasts are also being used to assist fishers plan the timing of their harvest of wild fisheries such as southern bluefin tuna. These approaches may represent a useful stepping stone to improve decision making and industry resilience at longer timescales.

Ecological simulations of the resilience of marine ecosystems can similarly inform managers on how to build resilience to future climate change, in order to prevent or mitigate potentially catastrophic shifts to alternative (often less productive) ecosystem states. Under a changing climate there are no historical analogs, and hence forward-looking strategies that are pre-tested against a broad range of plausible future outcomes are needed. MSE can be used to compare the performance of alternative future strategies, whilst taking into account the considerable uncertainty both in future climate variables, and their impacts. An example is presented of the use of MSE to integrate across biological and climate uncertainties, and test the performance and risks (biological, multispecies, economic) of alternative management strategies applied to the Torres Strait bêchede-mer (sea cucumber) fishery. Spatial management approaches based on adaptive feedback performed best and substantially reduced risks under future changing climate and biological uncertainty, compared with status quo management. Finally, we describe recent advancements in modeling capability to extend considerations beyond the biophysical domain as part of a broader socio-ecological framework. Models are the only approach that can provide such insight in a rigorous, repeatable and transparent fashion.

Keywords: Climate change, adaptive management, ecosystem shifts, resilience, socio-ecological 


\section{INTRODUCTION}

Climate change will increasingly impact human populations worldwide, both directly, for example, by inundation of infrastructure as a result of rising sea levels, or indirectly by, for example, impacts on individual physiology and life history that lead to shifts in the distribution and abundance of marine species (Doney et al. 2012). Extreme events such as cyclones are also projected to become more intense under climate change (IPCC 2012). In parallel increasing coastal development and population growth coupled with the need for sourcing food and income sources from the ocean will likely add further pressure to the marine environment. With these changes looming ahead, there is an urgent need to start developing climate-smart adaptation strategies (Stein et al. 2014) to support future ocean management.

In this paper, we first provide an overview of the flows from changes in physical drivers impacting biological systems through to their impact on socio-economic systems. We then suggest actions that could be taken as a perturbation propagates through the system, and examine modeling tools that can be used at each stage to road-test climate-smart management responses, strategies or to inform design of adaptation options.

A wide variety of ecological simulation models exist and have been reviewed elsewhere (Hollowed et al. 2000, Plagányi 2007, Hollowed et al. 2009), ranging from single species models coupled to physical oceanographic models (Hobday et al. 2011b), through models that focus on a key subset of the ecosystem only, such as MICE (Models of Intermediate Complexity for Ecosystem assessments) (Plagányi et al. 2014b), to whole ecosystem or end-to-end models such as Atlantis (Rose et al. 2010, Fulton et al. 2014). In addition, there is increasing use of management strategy evaluation (MSE) (Smith et al. 1999, Sainsbury et al. 2000) to evaluate how well different strategies perform (biologically, economically and socially) in responding to climate change impacts and perturbations. MSE frameworks are key examples of formal risk assessment methods, given their focus on the identification and modelling of uncertainties as well as in balancing different representations of resource dynamics (Sainsbury et al. 2000, Plagányi et al. 2013).

In this paper, we focus on three classes of tools to road-test climate-smart management responses, strategies or to inform the design of adaptation options, (1) multispecies models that advance our ability to anticipate or deal with major ecosystem shifts; (2) seasonal forecast models that can be used to proactively respond to projected changes, and (3) MSE to test the performance of alternative marine monitoring and management strategies to detect and respond to ecological changes caused by climate change.

\section{FRAMEWORK OF CLIMATE CHANGE IMPACTS AND POTENTIAL ACTIONS}

Changes in physical drivers, either gradually over time, or abruptly such as in the case of extreme events, impact on both biological and human communities. At an individual level, these changes impact the individual physiology and life history of species, for example individual growth, survival and phenology (Figure 1). Considered at the scale of populations, changes in these physical drivers result in changes in the abundance and distribution of species. This in turn impacts on the quantity, quality and composition of resources available for extractive (e.g. fisheries harvests) and non-extractive (e.g. marine tourism) human uses. There may be other important implications for management too, such as changes in the effectiveness of Marine Protected Areas (Hobday 2011). These changes may be temporary, such as in response to a perturbation to the system, or permanent, such as in the case of a regime shift to a new ecosystem state. For example, changes in fisheries catches, composition, catchability and spatial distribution of target species in turn have a number of flow on socio- economic impacts, such as changes to the supply chain - the processes that are linked to ensure transfer of marine natural resources from their landing site to the plates of consumers (Hobday et al. 2014, Plagányi et al. 2014c).

At each stage of the physical-biological-socio-economic progression, a number of actions are possible to increase understanding and prediction ability, as well as to improve management and community adaptation responses (Figure 1). For example, empirical and simulation methods that are capable of identifying when the system is approaching a tipping point can assist in preparing for the changes ahead, or in some cases can test mitigation methods to prevent changes to a less productive state (Section 3). Monitoring information combined with ocean forecast models may assist in forewarning and preparing for change (Section 4). Ecological simulation models can be used to forward project the altered abundance and distribution of species, and to pre-test how well alternative future management strategies perform against stated objectives (Section 5). Models of supply networks can assist in identifying critical elements and build resilience at key points in the network (Hobday et al. 2014, Plagányi et al. 2014c). In the subsequent sections, we provide examples of ways in which models can be used to assist in developing climate-smart adaptation strategies to support future ocean management. 


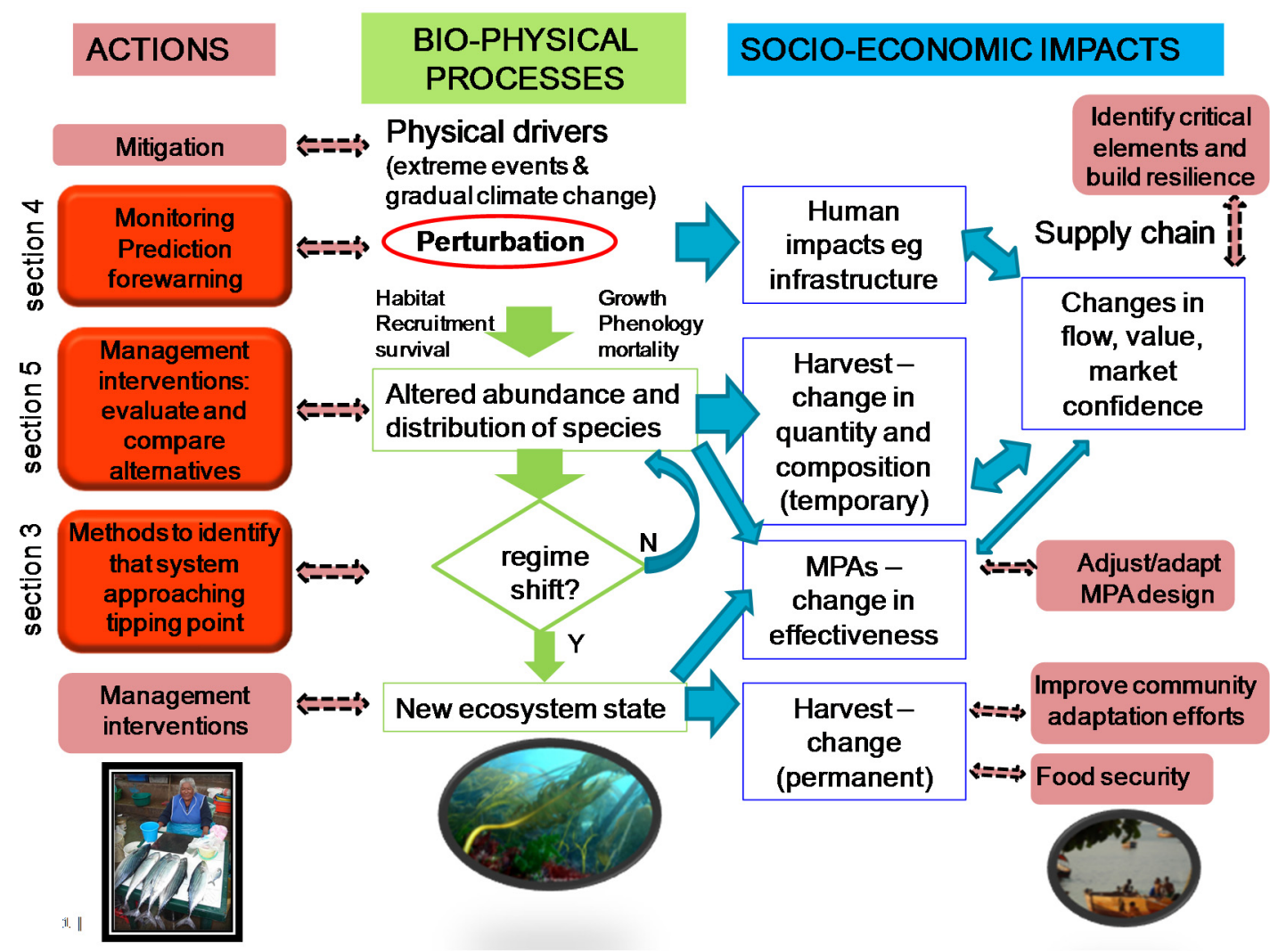

Figure 1. Schematic framework to map the flows from changes in physical drivers impacting biological systems through to their impact on socio-economic systems, shown together with management actions that

can support adaptation. A range of modeling tools can be used to road-test climate-smart management responses, strategies or to inform design of adaptation options, and the left hand references are to sections of this manuscript that provide examples of three approaches.

\section{MULTISPECIES MODELS TO ADVANCE OUR ABILITY TO ANTICIPATE OR DEAL WITH MAJOR ECOSYSTEM SHIFTS}

Shifts in ecosystem state, particularly unexpected ecological changes, can have major socio-economic repercussions, and attention is increasingly being focused on ways to increase or maintain system resilience (Hughes 1994, Folke et al. 2004). Resilience-based solutions include conserving biodiversity in a system and avoiding excessive depletion of individual, and particularly key, species in exploited systems. A central resilience concept is awareness of ecological thresholds - defined as the point where there is an abrupt change in an ecosystem quality, property or phenomenon, or where large ecosystem responses result from relatively small changes in an environmental driver (Groffman et al. 2006). These shifts or discontinuous effects (such as collapse in fisheries or sudden outbreaks of pest species) can occur when an ecological threshold or tipping point is passed (May 1977). There has been limited success to date in predicting thresholds (e.g. Litzow et al. 2013), but post-hoc studies show they are relatively common (e.g. Ling et al. 2015), and we should manage marine systems with this awareness. Furthermore, to understand a system's resilience to change, it is necessary to consider both "extreme event" resilience and "permanent press" resilience. In the former case, it is important to understand whether a perturbed system will recover or fall over and marine managers might be particularly interested in knowing if it is possible to nudge the system away from any tipping points.

Several studies have demonstrated that increasing variance is a leading statistical early warning signal of regime shifts and may be present in a variety of systems, including ecological, physical, social and financial (Scheffer and Carpenter 2003, Carpenter et al. 2011, Litzow et al. 2013). Plagányi et al. (2014a) used both modelling and empirical observations from a range of marine populations (starfish, abalone, penguins) to show that increasing variance in population monitoring data may signal a forthcoming abrupt decline, and also investigated the value at which the decline occurs and the extent of the decline. Moreover, using MICE models, they demonstrated that non-linear changes in population parameters (such as survival rate) below critical prey thresholds may contribute to the responses of predators to changes in their prey. Using models in 
this way assists in understanding the underlying mechanisms and response to perturbations, as well as providing managers with motivation to proactively monitor to mitigate ahead of projected changes (Morello et al. 2014, Plagányi et al. 2014a).

Similarly, ecological simulation models have been used to model the resilience of alternative ecosystem structures in order to answer questions such as whether overfishing has altered the system resilience. As an example, Blamey et al. (2014) simulated two alternative scenarios for an inshore ecosystem in the southern Benguela to explore whether overfishing of predatory fish could have been responsible for a lobster-induced regime shift. Under the overfishing scenario, lobsters invaded the range of abalone, depleted the urchins, changed the benthos and crashed the abalone population. In contrast, under the sustainable fishing scenario, lobsters again invaded the range of abalone, but were kept in check by higher fish density and predation and hence the system was more resilient to changes. While this is a retrospective example of alternative histories, such models also allow examination of alternative futures and provide insight on performance of alternative management approaches (such as ensuring that fish stocks are sustainably harvested) in avoiding future ecosystem shifts.

\section{SEASONAL FORECAST MODELS PROVIDE TRAINING FOR DECISION MAKERS AT A TACTICAL TIME SCALE}

While much is made of the long-term changes associated with climate change and the decisions that can lead to a sustainable future, shorter time scales are often viewed as more important by many decision makers. Inter-annual and seasonal variation in environmental conditions, such as ocean temperature, can change the growth rate of cultured animals, or the distribution of wild stocks. In turn these impacts may require changes in fishing or farming practices in order to maintain production of marine protein from fishing and aquaculture.

Forecasts based on dynamic ocean models, such as the Australian Bureau of Meteorology's Predictive Ocean Atmosphere Model for Australia (POAMA), provide the platform for applications for marine resource management. POAMA is a state-of-the-art seasonal forecast system based on a coupled ocean/atmosphere model and ocean/atmosphere/land observation assimilation systems and has been extensively assessed for regional forecasting of climate around Australia (e.g. Spillman et al. 2013). Such dynamical models can offer improved performance relative to statistical forecasts, particularly given baseline shifts in the environment due to climate change. Seasonal forecasting, based on POAMA products, is being used in a range of marine farming and fishing operations in Australia to reduce uncertainty and manage business risks (Hobday et al. 2015). Forecast variables include water temperature, rainfall and air temperature, and are considered useful up to approximately 4 months into the future, depending on the region and season of interest. Environmental forecasts with local statistical downscaling to provide higher spatial resolution have been developed for salmon (Spillman and Hobday 2014) and prawn (Spillman and Hobday 2014, Spillman et al. 2015) aquaculture industries, and influence decisions such as stocking density, frequency of disease treatment, outplanting times and feed mixes.

Species-specific habitat forecasts can also be made by combining environment forecasts with biological habitat preference data, typically with statistical approaches that link observed animal distribution data with environmental variables (Hobday et al. 2011a). These forecasts are appropriate for wild fisheries, where the distribution of species is of interest. Recently, such habitat forecasting has been developed to assist fishers plan the timing of their harvest of southern bluefin tuna (SBT) in the Great Australia Bight (Eveson et al. 2015). In recent years, SBT distribution in the fishing area had been different to past years, and thus fishing fleets were often located in the wrong place to access fish, which required extended periods at sea to move to the new areas. The SBT forecasts provide projections of distribution several months ahead of the start of the fishing season, and can help improve the economic efficiency of the quota-limited fleet by minimizing the time at sea chasing fish (Eveson et al. 2015). In a related application, forecasts of SBT habitat in eastern Australia have been used by managers to plan spatial management approaches to limit unwanted bycatch (Hobday and Hartmann 2006, Hobday et al. 2011a).

An important model evaluation step is to test the forecasting system on historical data which provides estimates of forecast skill and accuracy. This information helps managers and fishers decide when to "trust" a forecast (Hobday et al. 2011). Collectively, these examples have shown that seasonal forecasts are useful when a range of options are available for implementation in response to the forecasts. The use of seasonal forecasts in supporting effective marine management may also represent a useful stepping stone to improved decision making and industry resilience at longer timescales (Hobday et al. 2015). Nonetheless, it is increasingly recognized that uncertainties can compound when using multi-disciplinary approaches that combine oceanographic, fisheries and other marine models, and currently most integrative frameworks do not 
propagate the uncertainties of their constituent parts (Evans et al. 2015). The confidence ascribed to model predictions needs to take into account major uncertainties associated with all components (Evans et al. 2015). One solution is to develop approaches such as Management Strategy Evaluation (MSE) which are robust to a range of uncertainties.

\section{MSE AS A TOOL TO SIMULATION TEST CLIMATE SMART ADAPTATION STRATEGIES}

Faced with uncertainty about the future, an ability to test alternative approaches is valuable, and is now considered best practice in fisheries management. As functional relationships between environmental variables and fish production are explicitly incorporated in fisheries models (Keyl and Wolff 2008, Ianelli et al. 2011), these models can be used as operating models within Management Strategy Evaluation (MSE) frameworks. For example, Hollowed et al. (2011) evaluated alternative management strategies for Bering Sea walleye pollock (Theragra chalcogramma) and showed the potential increase in risk to the fishery when using harvest control rules under a regime with reduced mean recruitment.

Plagányi et al. (2013) used MSE to integrate across biological and climate uncertainties, and test the performance and risks (biological, multispecies, economic) of alternative management strategies applied to the Torres Strait bêche-de-mer (sea cucumber) fishery. A Reference Set (Rademeyer et al. 2007) of alternative model parameterisations was used to collectively capture some of the key biological uncertainties (e.g. alternative natural mortality estimates and steepness of the stock-recruitment relationship), as well as uncertainty of the likelihood (using high risk scenarios only versus assuming both high and medium risk scenarios occur) and severity (accounting for a doubling of the severity of each postulated effect) of climatechange effects. In this way Plagányi et al. (2013) simultaneously integrated across a range of biological and climate-impact uncertainties, and thereby tested a range of alternative harvest strategies to evaluate performance under changing climate. The alternative management scenarios included options that could be used in data-poor fisheries, as well as those requiring monitoring and spatial management (i.e. adaptive feedback in response to climate change). They found that status quo management would result in half the species falling below target levels, moderate risks of overall and local depletion, and significant changes in species composition. The three non-monitoring based strategies (spatial rotation, closed areas, multi-species composition) were all successful in reducing these risks, but with fairly substantial decreases in the average profit. Higher profits (for the same risk levels) could only be achieved with strategies that included monitoring and hence adaptive management. Spatial management approaches based on adaptive feedback performed best overall. Their study provides a demonstration of use of MSE to test the performance and adaptability of alternative harvest strategies in meeting fishery objectives, such as ensuring, low risk of depletion (overall and local), high probability of good catch and profit, low risk of changing the multi-species community composition and a high probability of managing through climate variability and change.

\section{CONCLUSIONS AND RECOMMENDATIONS}

In order to prepare for and respond to the impacts of climate change on marine species, habitats, infrastructure and human communities, a range of tools and approaches are required (Figure 1). This is both in terms of short-term abrupt impacts and longer term more gradual climate change. Models need not be overly complex - here we reviewed examples of how an intermediate complexity modelling approach could assist in understanding the underlying mechanisms as well as in identifying early warning signals that could be used to forewarn about the changes ahead. Similarly, forecasting models that build on existing dynamic ocean models can provide information on seasonal time scales, allowing proactive decision making by a range of users. Ecological simulations of the resilience of marine ecosystems can similarly inform managers on how to build resilience to future climate change, in order to prevent or mitigate potentially catastrophic shifts to alternative (often less productive) ecosystem states. Under a changing climate there are no historical analogs, and hence forward-looking strategies that are pre-tested against a broad range of plausible future outcomes are needed. MSE can be used to compare the performance of alternative future strategies, whilst taking into account the considerable uncertainty both in future climate variables, and their impacts. In this paper we highlight the potential of three modeling approaches - multispecies models, seasonal forecast models and MSE - to assist in preparing decision makers with climate-smart management responses and strategies to future expected climate-change impacts. Models are the only approach that can provide such insight in a rigorous, repeatable and transparent fashion. 
Plagányi and Hobday, Marine models to road-test climate-smart management responses and strategies

\section{ACKNOWLEDGMENTS}

This work was supported by the CSIRO Oceans and Atmosphere Flagship, with project funding provided by the Fisheries Research and Development Corporation and a range of industry peak bodies.

\section{REFERENCES}

Blamey, L.K., Plagányi, E.E. and G.M. Branch (2014). Was overfishing of predatory fish responsible for a lobster-induced regime shift in the Benguela? Ecological Modelling, 273, 140-150.

Carpenter, S.R., Cole, J.J., Pace, M.L., Batt, R., Brock, W., Cline, T., Coloso, J., Hodgson, J.R., Kitchell, J.F. and D.A. Seekell (2011). Early warnings of regime shifts, a whole-ecosystem experiment. Science, 332(6033), 1079-1082.

Doney, S.C., Ruckelshaus, M., Duffy, J.E., Barry, J.P., Chan, F., English, C.A., Galindo, H.M., Grebmeier, J.M., Hollowed, A.B., Knowlton, N., Polovina, J., Rabalais, N.N., Sydeman, W.J. and L.D.Talley (2012). Climate Change Impacts on Marine Ecosystems. Annual Review of Marine Science, Vol 4 , 11-37.

Evans, K., Brown, J. N., Sen Gupta, A., S. J. Nicol, J. N., Hoyle, S., Matear, R. and H. Arrizabalaga (2015). When $1+1$ can be $>2$ : Uncertainties compound when simulating climate, fisheries and marine ecosystems. Deep Sea Research II 113, 312-322.

Eveson, J.P., Hobday, A.J., Hartog, J.R., Spillman, C.M. and K.M. Rough (2015).Forecasting spatial distribution of SBT habitat in the GAB. FRDC Final Report 2012/239. Available at http,//frdc.com.au/research/final-reports/Pages/default.aspx. In Bulletin of the American Meteorological Society, Hobart, Tasmania.

Folke, C., Carpenter, S., Walker, B., Scheffer, M., Elmqvist, T., Gunderson, L. and C.S. Holling (2004). Regime Shifts, Resilience, and Biodiversity in Ecosystem Management. Annual Review of Ecology, Evolution, and Systematics, 35, 557-581.

Fulton, E.A., Smith, A.D.M., Smith, D.C. and P. Johnson (2014). An Integrated Approach Is Needed for Ecosystem Based Fisheries Management, Insights from Ecosystem-Level Management Strategy Evaluation. Plos One, 9(1).

Groffman, P., Baron, J., Blett, T., Gold, A., Goodman, I., Gunderson, L., Levinson, B., Palmer, M., Paerl, H., Peterson, G., Poff, N., Rejeski, D., Reynolds, J., Turner, M., Weathers, K. and J. Wiens (2006). Ecological thresholds, The key to successful environmental management or an important concept with no practical application? Ecosystems, 9(1), 1-13.

Hobday, A.J. (2011). Sliding baselines and shuffling species, implications of climate change for marine conservation. Marine Ecology, 32(3), 392-403.

Hobday, A.J., Bustamante, R.H., Farmery, A., Fleming, A., Frusher, S., Green, B.S., Lim-Camacho, L., Innes, J., Jennings, S. and A. Norman-López (2014). 16 Growth opportunities for marine fisheries and aquaculture industries in a changing climate. Applied Studies in Climate Adaptation, 139.

Hobday, A.J. and K. Hartmann (2006). Near real-time spatial management based on habitat predictions for a longline bycatch species. Fisheries Management and Ecology, 13(6), 365-380.

Hobday, A.J., Hartog, J.R., Spillman, C.M. and O. Alves (2011a). Seasonal forecasting of tuna habitat for dynamic spatial management. Canadian Journal of Fisheries and Aquatic Sciences, 68(5), 898-911.

Hobday, A.J., Hartog, J.R., Spillman, C.M., Alves, O. and R. Hilborn (2011b). Seasonal forecasting of tuna habitat for dynamic spatial management. Canadian Journal of Fisheries and Aquatic Sciences, 68(5), 898-911.

Hobday, A.J., Spillman, C.M., Eveson, J.P. and J.R. Hartog (2015). Seasonal forecasting for decision support in marine fisheries and aquaculture. Fisheries Oceanography doi 10.

Hollowed, A., A'mar, T., Barbeaux, S., Bond, N., Ianelli, J., Spencer, P. and T. Wilderbuer (2011). Integrating ecosystem aspects and climate change forecasting into stock assessments. ASFC Quarterly Report Research Feature, July-September, NOAA Alaska Fisheries Science Center.

Hollowed, A.B., Bax, N., Beamish, R., Collie, J., Fogarty, M., Livingston, P., Pope, J. and J.C. Rice (2000). Are multispecies models an improvement on single-species models for measuring fishing impacts on marine ecosystems? ICES Journal of Marine Science, 57(3), 707-719.

Hollowed, A.B., Bond, N.A., Wilderbuer, T.K., Stockhausen, W.T., A'mar, Z.T., Beamish, R.J., Overland, J.E. and M.J. Schirripa (2009). A framework for modelling fish and shellfish responses to future climate change. Ices Journal of Marine Science, 66(7), 1584-1594.

Hughes, T.P. (1994). Catastrophes, Phase-Shifts, and Large-Scale Degradation of a Caribbean Coral-Reef. Science, 265(5178), 1547-1551. 
Plagányi and Hobday, Marine models to road-test climate-smart management responses and strategies

Ianelli, J.N., Hollowed, A.B., Haynie, A.C., Mueter, F.J. and N.A. Bond (2011). Evaluating management strategies for eastern Bering Sea walleye pollock (Theragra chalcogramma) in a changing environment. Ices Journal of Marine Science, 68(6), 1297-1304.

IPCC (2012). Managing the Risks of Extreme Events and Disasters to Advance Climate Change Adaptation. A Special Report of Working Groups I and II of the Intergovernmental Panel on Climate Change. Cambridge University Press, Cambridge, UK, and New York, NY, USA.

Keyl, F. and M. Wolff (2008). Environmental variability and fisheries, what can models do? Reviews in Fish Biology and Fisheries, 18(3), 273-299.

Ling, S.D., Scheibling, R.E., Rassweiler, A., Johnson, C.R., Shears, N., Connell, S.D., Salomon, A.K., Norderhaug, K.M., Pérez-Matus, A., Hernández, J.C., Clemente, S., Blamey, L.K., Hereu, B., Ballesteros, E., Sala, E., Garrabou, J., Cebrian, E., Zabala, M., Fujita, D. and L.E. Johnson (2015). Global regime shift dynamics of catastrophic sea urchin overgrazing. Philosophical Transactions B, 370, 20130269.

Litzow, M.A., Mueter, F.J. and J.D. Urban (2013). Rising catch variability preceded historical fisheries collapses in Alaska. Ecological Applications, 23(6), 1475-1487.

May, R.M. (1977). Thresholds and Breakpoints in Ecosystems with a Multiplicity of Stable States. Nature, 269(5628), 471-477.

Morello, E.B., Plagányi, E.E., Babcock, R.C., Sweatman, H., Hillary, R.and A.E. Punt (2014). Model to manage and reduce crown-of-thorns starfish outbreaks. Marine Ecology Progress Series, 512, 167183.

Plagányi, É.E. (2007). Models for an ecosystem approach to fisheries. FAO Fisheries technical paper, 477.

Plagányi, E.E., Ellis, N., Blamey, L.K., Morello, E.B., Norman-Lopez, A., Robinson, W., Sporcic, M. and H. Sweatman (2014a). Ecosystem modelling provides clues to understanding ecological tipping points. Marine Ecology Progress Series, 512, 99-113.

Plagányi, E.E., Punt, A.E., Hillary, R., Morello, E.B., Thebaud, O., Hutton, T., Pillans, R.D., Thorson, J.T., Fulton, E.A., Smith, A.D.M., Smith, F., Bayliss, P., Haywood, M., Lyne, V. and P.C. Rothlisberg (2014b). Multispecies fisheries management and conservation, tactical applications using models of intermediate complexity. Fish and Fisheries, 15(1), 1-22.

Plagányi, E.E., Skewes, T.D., Dowling, N.A. and M. Haddon (2013). Risk management tools for sustainable fisheries management under changing climate, a sea cucumber example. Climatic Change, 119(1), 181-197.

Plagányi, E.E., van Putten, I., Thebaud, O., Hobday, A.J., Innes, J., Lim-Camacho, L., Norman-Lopez, A., Bustamante, R.H., Farmery, A., Fleming, A., Frusher, S., Green, B., Hoshino, E., Jennings, S., Pecl, G., Pascoe, S., Schrobback, P. and L. Thomas (2014c). A quantitative metric to identify critical elements within seafood supply networks. Plos One, 9(3), e91833.

Rademeyer, R.A., Plagányi, E.E. and D.S. Butterworth (2007). Tips and tricks in designing management procedures. Ices Journal of Marine Science, 64(4), 618-625.

Rose, K.A., Allen, J.I., Artioli, Y., Barange, M., Blackford, J., Carlotti, F., Cropp, R., Daewel, U., Edwards, K., Flynn, K., Hill, S.L., HilleRisLambers, R., Huse, G., Mackinson, S., Megrey, B., Moll, A., Rivkin, R., Salihoglu, B., Schrum, C., Shannon, L., Shin, Y.-J., Smith, S.L., Smith, C., Solidoro, C., St.John, M. and M. Zhou (2010). End-To-End Models for the Analysis of Marine Ecosystems, Challenges, Issues, and Next Steps. Marine and Coastal Fisheries, 2(1), 115-130.

Sainsbury, K.J., Punt, A.E. and A.D.M. Smith (2000). Design of operational management strategies for achieving fishery ecosystem objectives. Ices Journal of Marine Science, 57(3), 731.

Scheffer, M. and S.R. Carpenter (2003). Catastrophic regime shifts in ecosystems, linking theory to observation. Trends in Ecology and Evolution, 18(12), 648-656.

Smith, A.D.M., Sainsbury, K.J. and R.A. Stevens (1999). Implementing effective fisheries-management systems - management strategy evaluation and the Australian partnership approach. Ices Journal of Marine Science, 56, 967-979.

Spillman, C., Alves, O. and D. Hudson (2013). Predicting thermal stress for coral bleaching in the Great Barrier Reef using a coupled ocean-atmosphere seasonal forecast model. International Journal of Climatology, 33(4), 1001-1014.

Spillman, C., Hartog, J., Hobday, A. and D. Hudson (2015). Predicting environmental drivers for prawn aquaculture production to aid improved farm management. Aquaculture.

Spillman, C.M. and A.J.Hobday (2014). Dynamical seasonal ocean forecasts to aid salmon farm management in a climate hotspot. Climate Risk Management, 1, 25-38.

Stein, B.A., Glick, P., Edelson, N. and A. Staudt (2014).Climate-smart conservation, putting adaption principles into practice. National Wildlife Federation. 